Social Inequalities in Health

\title{
FEDERALISM AND DECENTRALIZATION: IMPACT ON INTERNATIONAL AND BRAZILIAN HEALTH POLICIES
}

\author{
Valéria Rodrigues Leite, Cipriano Maia de Vasconcelos, \\ and Kenio Costa Lima
}

\begin{abstract}
This article discusses the implications of decentralization in the light of international and Brazilian federalism, and its effects on public health policy. In a comparative analysis among countries, the authors find there is no single model; rather, each country has a unique structure of institutions and norms that have important implications for the operation of its health system. Brazil shares some similarities with other countries that have adopted a decentralized system and is assuming features ever closer to U.S. federalism, with a complex web of relationships. The degree of inequality among Brazilian municipalities and states, along with the budgetary imbalances caused by the minimal levels of resource utilization, undermines Brazil's constitutional principles and, consequently, its federalism. To ensure the constitutional mandate in Brazil, it is essential, as in other countries, to create a stable source of funds and increase the volume and efficiency of spending. Also important are investing in the training of managers, improving information systems, strengthening the principles of autonomy and interdependence, and defining patterns of cooperation within the federation.
\end{abstract}

The themes of federalism, intergovernmental relations, and decentralization are of growing interest in Brazilian and international scientific writing. Studies on these topics generally deal with questions related to power distribution, in the name of freedom. This helps ensure greater autonomy for localities, establishing political rights and financial resources, as well as defining obligations to federal units, mostly through decentralization and resource transfers. Fiscal federalism

International Journal of Health Services, Volume 41, Number 4, Pages 711-723, 2011

(C) 2011, Baywood Publishing Co., Inc.

doi: $10.2190 /$ HS.41.4.f

http://baywood.com 


\section{2 / Leite, de Vasconcelos, and Costa Lima}

entails the ways in which powers are distributed and fiscal, budgetary, and contributory intergovernmental relations are established.

The area of fiscal federalism is a subdivision of public finance studies that seeks to investigate resource transfer mechanisms between federal entities, from the normative and economic perspectives. Fiscal federalism is also concerned with well-being and fiscal equalization (1). According to Conti, fiscal federalism is "the study of how spheres of government interrelate from the financial viewpoint. It encompasses the analysis of how the state is organized, which type of federation is adopted, the degree of member autonomy, responsibilities attributed to them and, most importantly, how they will be financed" (2).

Thus, in considering the unique features of federalism and the trajectory of health policy in Brazil, it is important to discuss the recent period during which the country is experiencing a redefinition aimed at designing a new structure of federal relations (3) and correcting regional imbalances through decentralization. Success in the decentralization process is highly dependent on the funds available to fulfill local responsibilities and priorities. When the evolution of federal social spending is examined by area, health-related spending in Brazil is found to be at minimal levels (4). This compromises the application of constitutional principles and, in turn, federalism itself (5).

The present study joins this debate, presenting a comparative analysis among countries of the federative question, with a specific focus on the health area. We discuss decentralization and resource transfers, two of the main elements characterizing fiscal federalism. Financing data indicate low public spending in Brazil, in what is considered a universal health system. Thus, national and local studies have stressed the need for increased health resources to guarantee the constitutional mandate.

To that end, we carried out a theoretical-conceptual review of federalism, decentralization, and transfers. Fiscal federalism is analyzed by considering the question of financing and spending as presented in some recent studies, with data from the Organization for Economic Cooperation and Development (OECD), World Health Organization (WHO), Pan American Health Organization, Brazilian Institute of Geography and Statistics (IBGE), and Institute of Applied Economic Research, among others. We begin by discussing the general aspects of federalism and how federal institutions influence power distribution through transitory institutional arrangements. We then demonstrate the relationship between federalism and decentralization. The latter, which has increasingly been adopted as an alternative to centralized structures, is an element of many health system reforms; transfers play an important role in resource decentralization by seeking to decrease regional differences. Finally, we discuss federalism in Brazil-specifically, National Health System (SUS) financing, a mix of public and private resources and spending that is insufficient for the needs of the population. The health sector is suffering from inefficiency, lack of equipment, and inadequate infrastructure. 


\section{GENERAL ASPECTS OF FEDERALISM}

Federalism is a form of government that, while admitting differences among states, seeks to integrate them into an organic whole. The amalgamation of regional divergences and similarities and the political pendulum between local and central governments demonstrate the importance of this form of government, as well as - according to many - its democratic nature. In this sense, "federalism is regarded as a form of power distribution, with many supporters demonstrating the similarities between democracy and federalism, and considering it the most progressive form of the state" (6).

Elazar (7) indicates that federalism shares political power in the name of freedom. Freedom here gains a sense of protection given to citizens against the abuses of central power, through the advantages of small size. Subnational entities potentially allow for greater control of policy decisions by the people and grant the right-to-participate to minority groups, not just to the majority.

We can say, based on the theory of the modern federal state, that federalism concerns a particular form of geopolitical organization of state power that distinguishes it from the unitary and confederative models in relation to key aspects of structure and function. Federalism divides political authority of the state (sovereignty) and exercise of power (government) into multiple sovereign centers, defined geographically and coordinated with each other. The consequence of this plurality is not the elimination of central power but the existence of an autonomous national government, voluntarily maintained by the union of all citizens to achieve common objectives without jeopardizing the rights that exist in the constituent territories and their diversity of interests (8).

In its modern form, federalism emerged simultaneously with the economic concept of the market. Although this was not the only reason for creating federations, creation of a common market and national integration were made possible by political accords that harmonized economic policies across different areas. From these accords, a government framework was born, capable of enforcing the law, guaranteeing property rights and contracts, preserving cultural characteristics, accommodating political demands, and maintaining the governmental functions of constituent communities (8).

At present, even in unitary states, space is increasingly opening up to ensure greater autonomy to localities and to create structures that can accommodate heterogeneity and resolve conflicts. Yet, as demonstrated by creation of the European Union, globalization has been encouraging the organization of supranational federations to maintain political, economic, and social cohesion (8).

Some authors claim that there is no universally valid definition of federalism, the appropriate division of power, and the correct institutional form for a federative organization (9). In this view, institutional arrangements are always transient, the result of a necessary and positive tension and disharmony between the constituent parts of the state, leading to a continuous negotiation process. Although 


\section{4 / Leite, de Vasconcelos, and Costa Lima}

the analysis of institutional arrangements is essential for an understanding of federalism, our understanding of the federal state is not complete until we consider the characteristics and values of each society that allow for the creation and functioning of its institutions (10).

In general, studies of federalism use as a reference the U.S. model, one that allows the "negotiation between individual parts to create and maintain the federal state, but does not take into account the trajectory of unitary states that have become federations," more typical of the recent period (11). Stepan (12) goes beyond "coming together as federations" represented by the U.S. model, adding a more comprehensive and updated analytical framework that necessarily includes "holding together federations," examples of which include the constitutions of Spain (1976) and Belgium (1993). There, and in other federal states such as Germany, local power is one of the most relevant dimensions of participatory democracy, whose positive influence in setting local priorities and in public policy management is indisputable.

Gibson and colleagues state that "the design of federal institutions has implications for the way in which power is distributed among federal actors. Institutions conform (and reform) the distribution of power between actors geographically and the institutional distribution of power between actors at different levels of government" (13). Through its institutions, the federal state interacts with the asymmetries of society, granting certain political rights, providing financial resources, and defining the obligations of the constituent units of the federation through infrastructure and public policies. While some institutions reflect these asymmetries, others compensate by trying to accommodate conflicting interests, managing the nation's federal balance.

Federal institutions - the plan of their structures, rules, and processes - give shape to the federation itself. Introducing their own dynamics and characteristics in different spheres of public policy, federal institutions help shape the boundaries of real power between entities at different levels of government, or at the same level, throughout the history of each society. However, federalism and its principles are also revealed in the fiscal dimension, especially in the distribution of economic power-funding at different levels of government, through the definition of tax structure, forms of revenue, and forms of intergovernmental transfer mechanisms (14).

Elazar (7) believes that federal institutions lend substance to the combination of two basic principles: government autonomy and interdependence, the classic formula called "self-rule plus shared rule" that underlies the federal pact. The principle of autonomy is that through which federal entities establish their rules of self-governance (self-rule) and define the range of actions that other levels of government can impose on them. The principle of interdependence (shared rule) defines the patterns of cooperation within the federation, establishing a practice of negotiation capable of defining common goals between governments. Interdependence favors a complementarity between the spheres of government, 
the need to strengthen federal ties, and the need to create national parameters respecting regional diversity, thus reducing the risk of breakdown or failure.

Elazar points to "non-centralization" as one of the key elements that characterizes federalism, since subnational levels of government do not act by transfer or simple delegation of central power (as in unitary states) and do not establish a fixed order between federal entities. Regardless of how powers are divided, national and subnational governments have some independence in their spheres of action and final decisions. Moreover, their authority cannot be removed without mutual consent, except when found to be in violation of federal principles.

Accordingly, in a comparative study involving 12 federations, Watts (15) asserts that, in practice, there is no single and permanent model of the centerperiphery relationship in countries that adopt federalism. The oscillation between centralization and decentralization is intrinsic to federal systems and is present in the trajectory of these countries. Watts also highlights the difficulty of measuring the degree of centralization versus decentralization, since there are multiple possible arrangements in the legislative, administrative, and fiscal plans, constitutional rules, and even the decision-making process, which show distinct levels of dependence, political influence, and fiscal control between spheres of government.

\section{FEDERALISM AND DECENTRALIZATION IN HEALTH SYSTEM MODELS}

Arretche (5), on analyzing the relationship between federalism and decentralization, notes that the degree of centralization in the distribution of administrative responsibilities has varied greatly throughout the history of federal countries, but without changing federalism's essential character: the political authority given to local governments. In his reflections, he tends to separate the origins of sovereignty granted to subnational governments under federalism-derived mainly from direct popular vote, autonomy of the tax base, and in some cases, their own military-from the factors that influence the administrative power of a policy throughout different levels of government.

In the context of federations, whether through relocation or consolidation, decentralization interferes with the balance between the autonomy and interdependence of governments and thus often requires the strengthening of coordination mechanisms - not limited to the imposition of joint participation, but also including the establishment of partnerships approved by federal entities. Thus, decentralization is complex, involving cooperation and competition, agreements and vetoes, and joint decisions between levels of government (16).

Decentralization has been implemented in countries with stable democracies as an alternative to centralized decision-making institutions, imposed during construction of their welfare states-a Keynesian inspiration. In some European countries, such as France, it was hoped that decentralization would operate as an 


\section{6 / Leite, de Vasconcelos, and Costa Lima}

instrument of democratic radicalization, to expand the channels of political participation (17). In other countries, such as Italy, decentralization brought expectations of a revitalization of regional governments, which had been depleted of their power by excessively centralized unitary states (18). In yet other countries, such as Belgium and Spain, federalism was in great demand as an assertion of political autonomy for politically underrepresented ethnic groups in unitary states with majoritarian electoral rule (12).

In the wake of these hopes and expectations, some countries remained unitary states and adopted extensive programs of decentralization, as in the case of France and Italy (19). The United Kingdom returned certain prerogatives to Scotland, Wales, and Northern Ireland. In other cases, however, federal policy solutions flourished. Belgium (1993), South Africa (1996), and Spain (1978) have adopted fully or partially federal systems. In northern Italy, there is strong pressure for the adoption of federalism. Much of the integration process of the European Union is based on federal principles (15).

Decentralization is also an aspect of many health system reforms. Some countries have reorganized their health services to consolidate primary care. A comparison between 12 Western industrialized nations indicates that countries with a stronger orientation to primary care are more likely to have better levels of health and lower costs. Almost all countries are struggling with their own reforms. Many nations are attempting to finance their health systems according to egalitarian principles (20).

Intergovernmental transfers play an important role in the decentralization process, ensuring resource distribution. They reinforce the role of central power in most countries by correcting fiscal inequalities, thereby promoting equalization among subnational units. This establishes revenue and spending levels compatible with responsibilities, social rights, and obligations, providing services required by existing public policies, as well as health care access and investment.

On intergovernmental financial transfer in particular, Banting and Corbett (3) caution that it is based on the belief that citizens in different regions of the country are entitled to similar benefits and services, without having to pay significantly different taxes. Transfer systems tend to diminish the risk that regional differences, at the tax and benefit levels, will influence the migration of capital and people within the country, and to compensate for the relationship between health needs and financing capacity that benefits the most favored regions.

For countries such as Germany, Canada, Australia, and, to a lesser extent, Switzerland, the "solidarity transfers" are necessary to ensure a reduction in the budgetary differences between intermediate levels of government, though they do not always consider the effective needs of spending. These countries are constantly concerned about accountability. Sovereign subnational governments use revenue from intergovernmental transfers, some not earmarked for specific purposes, on local priorities for their own voters (14). 
In Brazil, the decentralization mechanisms for financing health policies are very fragile. Federal transfers do not take into account the real possibilities for financial support and increased spending from revenues by the subnational spheres themselves, and the resources transferred are insufficient to overcome the budgetary limitations in underdeveloped jurisdictions. In the context of this study, there are many challenges for the health sector. These include the need for alterations in existing macroeconomic policy, prioritization of public health policy, and changes in the institutional rules of Brazilian fiscal federalism (14).

\section{FEDERALISM AND THE BRAZILIAN HEALTH SYSTEM}

Throughout its history, Brazil has seen major changes in its federal arrangements and institutions, which have nevertheless survived even long periods of military dictatorship and authoritarianism. Federalism emerged as the necessary way to bridge the country's enormous regional disparities, not as a response to ethnic, linguistic, and religious cleavages, as these issues never assumed great prominence on the Brazilian political agenda (14). According to Souza, "in every historical moment, these disparities were accommodated in different ways and these differences are recognized in the constitutional design and tax structure" (21).

With its economic and historical background, the structure and recent evolution of the Brazilian federation takes on features increasingly close to the North American model, as shown by international comparisons of federal experiences or fiscal decentralization. Shah (22) has classified both as having assignments that are not distributed in an orderly fashion, with a clear and precise task division, but occur in a complex web of relationships. Sometimes more than one government performs the same function in certain regions or time periods; at other times, one government takes charge of the competencies of another sphere; and at yet other times, the government is absent or spending is scarce.

The Brazilian federal map contrasts with that of the United States with respect to both the fiscal autonomy of localities and the nature of their decision-making processes. The United States stands as a federal system of government in which decentralized decisions are consistent with urbanization and the concentration of people in small cities and urban areas, even allowing for direct participation of the population in local decisions by way of plebiscite (8). Another point is that Brazil has three levels of government: federal, state, and municipal. The inclusion of municipalities as federal entities is a unique feature of Brazilian federalism. Decisions and funding issues, in most cases, migrate from the federal government to state and municipal entities. The task of establishing rules for a federation the size of Brazil, a union of 27 states and 5,562 municipalities, is a complex one. It is in this universe of municipalities, with regional disparities, that the new model proposed in the Constitution has a profound impact. 


\section{8 / Leite, de Vasconcelos, and Costa Lima}

With respect to health, the Brazilian Constitution states that "on the one hand, private enterprise is free to operate (article 199); on the other, it is a citizens' right (article 196) - a paradox that tends to undermine public health financing" (23). Thus, the financing matrix of total health spending must distinguish public from private resources. After the Constitution, the government established the SUS, financed by federal taxes and social contributions. Municipal taxes and resource transfers that finance social spending, particularly health spending, are the primary sources at the municipal and state levels. The private system is familyand industry-financed.

Brazil has a duplicate model in which the private sector offers coverage for nearly all services available in the public sector, but the clientele of private medicine continue to use the public system (see 24). This situation also exists in England, where private coverage has been used to reduce waiting times in the public sector $(25,26)$.

Almost all OECD countries have public health systems consisting of a regulated set of providers, with policies, programs, and activities financed by the state. Several models, such as those in Canada, Sweden, the United Kingdom, Spain, and Portugal, rely on general taxation revenues. Germany and France sustain their public health systems primarily with corporate and employee contributions. Some countries supplement public financing with user fees. The United States has a typical free-market health care system, consisting mostly of insurance plans financed by employers, individuals, or groups. There are also insurance models with public financing for specific populations, such as the elderly and low-income groups. Among the OECD countries, the United States stands out for its limited public financing in the system as a whole (public and private), accounting for slightly more than 40 percent of total health spending (27).

Most universal systems, though not comprehensive, are mainly publicly financed, as in the OECD countries. The health system in Brazil is not only universal but also comprehensive. However, public spending represents only 46 percent of the total, very similar to that in the United States with its free-market model based on private insurance (28).

There seems to be a contradiction between the redistribution model proclaimed by the Brazilian Constitution and the level of public health spending. The problem in Brazil is that public spending is too low for the country to have an effective health system with universal, comprehensive coverage. In the OECD countries, financing from public sources for health systems accounts for an average of 70 percent of total spending, ranging from 67.5 percent in Australia to 84.1 percent in Norway. The United States and China, despite their cultural, political, and economic differences, are the most important exceptions to this rule, since their private spending levels are more than 50 percent of the total (29). In Brazil, however, public participation in total health spending is 42 percent $(30,31)$. It may be the only country with a legally mandated universal health system where private spending exceeds public spending (32). 
As a percentage of GDP (gross domestic product), total health spending (public and private) in Brazil is 8.4 percent $(30,31)$. This figure is low when compared with the United States (15.7\%), but is equal to or just slightly lower than in other OECD countries, such as the United Kingdom (8.4\%), Spain (8.5\%), Canada (10.1\%), and Australia (8.9\%), which also have universal systems $(31,32)$.

In relative terms, the proportion of public spending on health in Brazil $(45.9 \%)$ is comparable with that in the United States $(44.6 \%)$. In per capita terms, including private spending on health, Brazil spends US\$597, slightly below the average for Latin American countries (US\$622) and about one-fifth that of the average for selected countries of the OECD. The United States spends 10 times more on health per capita than does Brazil, while its per capita income is 5 times greater (26).

The British National Health Service, albeit less pluralist, is similar to what is described in the Brazilian Constitution, with public health spending accounting for 85.7 percent of allocated resources. It is important to point out that there is an ongoing public debate in Brazil on whether the system is sufficiently financed and whether it should be privatized (26).

Mattos and Costa (33), in considering the subject of SUS financing, argue that public spending on health in Brazil is insufficient to cover the health needs of the population. The minimal levels of spending may result in government agencies losing the power to implement their budgets. Watts (15) reflects that autonomy at the local level is a function not so much of sharing in the transfers of total revenue available as of the conditions imposed on subnational government spending.

Moreover, the health sector is experiencing a deterioration of corporations and institutions. The widespread depoliticization is expressed in the alienation of health professionals, particularly doctors, from the public health system. These professionals do not perceive the SUS as a collective project of society. On the one hand, this is partly the result of how the government has been dealing with health professionals in addressing the processes and administration of public health in Brazil. On the other hand, the political debate in public areas such as health is crystallized in the modus operandi, repetitive speeches, and role of representative bodies (professional or otherwise) hamstrung by disputes between micro-powers and false ideological confrontations that conceal the lack of proposals and autonomy to address the real obstacles-in reference to the health system that Brazilian society can actually afford (34).

\section{CONCLUDING THOUGHTS}

Federalism has been adopted in several countries, with the aim of transferring resources and administrative and fiscal responsibilities to subnational entities. These transfers provide greater autonomy, political power, and protections to citizens, creating structures that can accommodate regional differences. Federalism has different origins, though based on the model of U.S. federalism, 
which entails negotiation between the individual parts to create and maintain the federation. It adopts decentralization as its main instrument of implementation, with the expectation of strengthening local governments and radicalizing democracy.

From a glance at federalism in a selection of countries, we can conclude that there is no single model. The particular structures of institutions and norms of each country have important implications for the functioning of health systems in terms of access and services, division of labor between levels of government, and the nature of fiscal relations, which strongly affects the distribution of health care among citizens. However, health policy is never purely local in any federation. Regional governments participate in the definition of central government policies. There are fiscal relations across levels of government and mechanisms for coordinating their respective programs. Yet the central government and the decentralization of resources play an important role in all systems.

Decentralization entails the distribution of functions among local governments in the management of planning and resources, through various institutions, in an attempt to construct the limits of power between different levels of government. It is the federated institutions that design the federation. "The way power is distributed is related to the design of federal institutions" (13). Power is distributed among entities that interact with society according to structures with some degree of independence in their sphere of action and final decision-making.

In this sense, the trajectory of federalism in Brazil has similarities to international federalism, driven by a consensus on decentralization, as in France, Italy, Colombia, Chile, Bolivia, and other countries that have relied on a variety of ideologies. Brazilian federalism assumes features ever closer to North American federalism, with a complex web of relationships. However, despite its politicalinstitutional performance shaped by the U.S. Constitution, Brazilian federalism has never reproduced the historical process of harmonization and interests achieved by the United States. The federal map of Brazil contrasts with that of the United States in both the fiscal autonomy of localities and the nature of their decision-making. The existence of conflicting interests has hampered the construction of cooperative agreements in Brazil. With respect to fiscal federalism, the pattern of transfers does not favor greater equality in public spending on health (35), which is at minimal levels and generates inequities among the subnational units. Further differences are evident in financing. "Brazil is the only country with a universal health system where private spending is greater than public spending" (32). "The low amount of resources spent in Brazil compromises the application of constitutional principles and consequently, federalism. The health sector is suffering from inefficiency, lack of equipment and inadequate infrastructure" (5).

Despite advances in health care, there continues to be a need for federal coordination that allows responsibilities and priorities to be fulfilled at the 
local level, as well as health investments. It is important to establish the model to be used by the state to organize the health care system, including the mixture of public and private services and the relative weight of public financing and private resources. Therefore, the challenge of building a logic of federal coordination remains, and Brazil can learn from the examples of Germany, Australia, Belgium, Canada, the United States, and other countries, in their per capita expenditure, performance of local governments, and institutional channels. It is this perspective that frames the debate on the role of decentralization of health care in the Brazilian federation. In summary, then, as studies on federalism continue to evolve, the hope is that new insights will emerge regarding the causal mechanisms underlying the relations between health spending, institutional questions, and political factors.

\section{REFERENCES}

1. Nóbrega, M. Federalismo seletivo e equalização: O novo modelo de gestão fiscal e o impacto nos entes subnacionais. www.esmape.com.br/downloads/equalização fiscal.pf (accessed April 25, 2010).

2. Conti, J. M. Federalismo Fiscal e Fundos de Participação, pp. 75-124. Juarez de Oliveira, São Paulo, 2001.

3. Banting, K., and Corbett, S. Federalismo y políticas de atención a la salud. In Federalismo y políticas de salud: descentralización y relaciones intergubernamentales desde una perspectiva comparada, ed. C. Auclair and C. H. Crrasco. Foro de Federaciones, Ottawa; Instituto Nacional para el Federalismo y Desarrollo Municipal, Ciudad de México [2002?].

4. Gerschman, S., and Viana, A. L. A. Descentralização e desigualdades regionais em tempos de hegemonia liberal. In Saúde e democracia: história e perspectivas do SUS, ed. N. Trindade Lima et al., pp. 301-351. Ed. Fiocruz, Rio de Janeiro, 2005.

5. Arretche, M. Relações federativas nas políticas sociais. Educ. Soc. 23(80):25-48, 2002.

6. Baracho, J. A. O. Teoria geral do Constitucionalismo. Revista de Informação Legislativa, Brasília, Senado Federal, No. 91, July-September 1986.

7. Elazar, D. J. Exploring Federalism. University of Alabama, Tuscaloosa, 1987.

8. Dain, S. Do Direito Social à Mercadoria. Thesis, Universidade do Estado do Rio de Janeiro, 2000.

9. Fiori, J. L. O federalismo frente ao desafio da globalização. Série Estudos em Saúde Coletiva, No. 15. Instituto de Medicina Social, Universidade do Estado do Rio de Janeiro, Rio de Janeiro, 1995.

10. Levi, L. Federalismo. In Dicionário de política, Ed. 5, ed. N. Bobbio, N. Matteucci, and G. Pasquino, Vol. 1, pp. 475-486. Universidade de Brasília, Brasília; Imprensa Oficial do Estado, São Paulo, 2000.

11. Kugelmas, E., and Sola, L. Recentralização/descentralização: dinâmica do regime federativo no Brasil dos anos 90. Tempo Social 11(2):63-83, 1999.

12. Stepan, A. Para uma nova análise comparativa do federalismo e da democracia: federações que restringem ou ampliam o poder do demos. Dados-Revista de Ciências Sociais 42(2):197-251, 1999. 
722 / Leite, de Vasconcelos, and Costa Lima

13. Gibson, E. L., Calvo, E. F., and Falleti, T. G. Federalismo realocativo: sobrerepresentação legislativa e gastos públicos no hemisfério ocidental. Opinião Pública 9(1):98-123, 2003.

14. Lima, L. D. Federalismo, relações fiscais e financiamento do Sistema Único de Saúde: a distribuição de receitas vinculadas à saúde nos orçamentos municipais e estaduais[tese]. Universidade do Estado do Rio de Janeiro, Instituo de Medicina Social, Rio de Janeiro, 2006.

15. Watts, R. L. Comparing Federal Systems in the 1990s. Institute of Intergovernmental Relations, Ont., 1996.

16. Abrucio, F. L., and Samuels, D. Descentralização e coordenação federativa no Brasil: lições dos anos FHC. Texto-base apresentado no Seminário Políticas Públicas e Pacto Federativo: a descentralização no Brasil. Mimeo. Curso de Aperfeiçoamento para a carreira de Especialista em Políticas Públicas e Gestão Governamental da Escola Nacional de Administração Pública, November 2004.

17. Rosavallon, P. P. Local, pouvoirs locaux. Entrevista, October 1993, pp. 39-46.

18. Putnam, R. D. Comunidade e democracia: a experiência da Itália moderna. FGV, Rio de Janeiro, 1996.

19. D'arcy, F., and Baena, D. A. M. Décentralisation en France et en Espagne. Economica, Paris, 1986.

20. Starfield, B. Atenção Primária-equilíbrio entre necessidades de saúde, serviços e tecnologia. UNESCO and Ministério da Saúde, Brasília, 2002.

21. Souza, C. Federalismo e gasto social no Brasil: tensões e tendências. Lua Nova $52: 5-28,2001$.

22. Shah, A. A Fiscal Needs Approach to Equalization Transfers in a Decentralized Federation. Policy Research Working Paper Series No. 557. World Bank, Washington, DC, 1990.

23. Ocké-Reis, C. O. Uma reflexão sobre o papel da ANS em defesa do interesse público. RAP 39(6):1303-1318, 2005.

24. Wasen, J., Greb, S., and Okma, K. G. H. The role of private health insurance countries. In Social Health Insurance in Western Europe, ed. R. Saltman, R. Busse, and J. Figueras, pp. 227-247. Open University Press, Milton Keynes, UK, 2004.

25. Organization for Economic Cooperation and Development. Reviews of Regulatory Reform: Brazil Strengthening Governance for Growth. Paris, 2008.

26. Ocké-Reis, C. O. A constituição de um modelo de atenção à saúde universal: uma promessa não cumprida pelo SUS? IPEA texto para discussão. IPEA, Rio de Janeiro, 2009.

27. Pereira, V. H. $3^{\text {a }}$ Conferência de Gestão Hospitalar dos Países de Língua Portuguesa, Lisbon, November 2008.

28. Projeto PIB-Perspectiva de Investimento no Brasil-Perspectiva de Investimento na saúde. Instituto de economia da UFRJ, Rio de Janeiro; Instituto de Economia da Unicamp, São Paulo, 2009.

29. World Health Organization. The World Health Report 2006: Working together for Health. Geneva, 2008. www.who.int/whr/2006/en.

30. Instituto Brasileiro de Geografia e Estatística. Estatísticas da Saúde-Assistência Médico-Sanitária. Rio de Janeiro, 2006.

31. World Health Organization. Europe HFA Database, January 2009. www.euro.who.int/ hfadb (accessed February 14, 2009). 
Federalism, Decentralization, and Health Policies / 723

32. Piola, S. F. 2010. www.valoronline.com.br.

33. Mattos, R. A., and Costa, N. R. Financiando o SUS: algumas questões para o debate. Trab. Educ. Saúde 1(2):315-333, 2003.

34. Bodstein, R., et al. Comentários sobre a Estratégia de Saúde da Família e o SUS. Ciência e Saúde Coletiva 14(Suppl. 1):1336-1345, 2009.

35. Lima, L. D. Conexões entre o federalismo fiscal e o financiamento da política de saúde no Brasil. Ciência e Saúde Coletiva 12(2):511-522, 2007.

Direct reprint requests to:

Valéria Rodrigues Leite

Federal University of Rio Grande do Norte

Department of Economics

Av. Amintas Barros 2141, edf. Menton - apto 201

Bom Pastor - CEP 59062-250, Natal, RN

Brazil

leite@ufrnet.br 